\title{
An Aerial Survey Technique for the Forest-Dwelling Ecotype of Woodland Caribou, Rangifer tarandus caribou
}

\author{
Réhaume Courtois ${ }^{1,2,5}$, André Gingras ${ }^{3}$, Claude Dussault ${ }^{4}$, Laurier Breton $^{1}$ and \\ JEAN-PIERRE OUELLET ${ }^{5}$
}

${ }^{1}$ Société de la faune et des parcs du Québec, Direction de la recherche sur la faune, 675, René-Lévesque, Est, $11^{\mathrm{e}}$ étage, boîte 92 , Québec, Québec G1R 5V7 Canada ; e-mail : rehaume.courtois@fapaq.gouv.qc.ca

${ }^{2}$ Université Laval, Département de foresterie et de géomatique, Cité Universitaire, Ste-Foy, Québec G1K 7P4 Canada

${ }^{3}$ Société de la faune et des parcs du Québec, Direction de l'aménagement de la faune, 818, boulevard Laure Sept-Îles, Québec G4R 1 Y8 Canada

${ }^{4}$ Société de la faune et des parcs du Québec, Direction de l'aménagement de la faune, 3950 boulevard Harvey, 4 e étage, Jonquière, Québec G7X 8L6 Canada

${ }^{5}$ Université du Québec à Rimouski, Département de biologie et des sciences de la santé, Centre d'études nordiques, 300, Allée des Ursulines, Rimouski, Québec G5L 3A1 Canada

Courtois, Réhaume, André Gingras, Claude Dussault, Laurier Breton, and Jean-Pierre Ouellet. 2003. An aerial survey technique for the forest-dwelling ecotype of Woodland Caribou, Rangifer tarandus caribou. Canadian Field-Naturalist 117(4): $546-554$

Accurate and precise population estimates for the forest-dwelling ecotype of Woodland Caribou (Rangifer tarandus caribou) are very difficult to obtain because these Caribou are found at very low densities and in small herds dispersed over large areas. In order to suggest a standardized method, data from aerial surveys conducted in 1991 and 1993 (12 $000 \mathrm{~km}^{2}$ blocks) were used to simulate various survey scenarios. Simulations showed that all the major groups of Caribou would have to be found and counted to obtain a confidence interval of $\pm 20 \%(\alpha=0.10)$. We tested this technique in a survey carried out in winter 1999 in a $42539 \mathrm{~km}^{2}$ study site, opting for a total coverage carried out in two phases. In phase one, we used an airplane, flying northsouth transects spaced $2.1 \mathrm{~km}$ apart so as to detect most Caribou track networks. In phase two, a helicopter was used to count and determine the sex and age classes (calves/adults) of Caribou found in phase one. Using 20 radio-collared Caribou, the visibility rate of Caribou groups (phase one) and that of Caribou within the groups (phase two) were estimated at 0.90 and 0.94 respectively for an overall rate of $0.85(\mathrm{SE}=0.08 ; \alpha=0.10)$. The corrected density was estimated at $1.6 \mathrm{Caribou}$ per $100 \mathrm{~km}^{2}$ with a $15 \%$ confidence interval $(\alpha=0.10)$. The survey cost approximately $\$ 4 / \mathrm{km}^{2}$, which is lower than that of two previous surveys $\left(\$ 7 / \mathrm{km}^{2}\right)$. Two main factors contributed to diminish costs: (1) the use of long-range airplanes (5-7 hours flying range) in phase one to minimize travel between the airports and the study site, and (2) the use of helicopters only in phase two for counting and determining the age and sex of the Caribou.

Key Words: Woodland Caribou, Rangifer tarandus caribou, accuracy, aerial survey, bias, cost, density, forest-dwelling ecotype, simulation, visibility rate, Quebec.

Il est très difficile d'obtenir des estimations de population exactes et précises pour l'écotype forestier du Caribou des bois (Rangifer tarandus caribou) parce qu'on le retrouve en très faibles densités et qu'il est distribué en petites hardes réparties sur de vastes superficies. Les résultats de deux inventaires aériens réalisés en 1991 et $1993\left(12000 \mathrm{~km}^{2}\right)$ ont été utilisés pour simuler divers scénarios d'inventaire afin de suggérer une méthode standardisée. Les simulations ont montré qu'il fallait trouver et recenser tous les groupes principaux pour obtenir un intervalle de confiance de $\pm 20 \%(\alpha=0,10)$. Nous avons testé cette approche dans un site d'étude de $42539 \mathrm{~km}^{2}$ où nous avons opté pour un plan en deux phases. En phase un, l'avion a été utilisé pour couvrir totalement le site d'étude selon des virées équidistantes de 2,1 km afin de détecter la plupart des réseaux de pistes. L'hélicoptère fut utilisé en phase deux pour dénombrer et sexer les Caribous dans les réseaux de pistes détectés en phase un. D'après 20 Caribous munis de colliers émetteurs, le taux de visibilité global était de 0,85 ( $\mathrm{SE}=0,08 ; \alpha=0,10)$, soit 0,90 en phase 1 et 0,94 en phase 2 . La densité corrigée était de 1,6 Caribou par $100 \mathrm{~km}^{2}$ avec une erreur relative de $15 \%(\alpha=0,10)$. L'inventaire a coûté $4 \$ / \mathrm{km}^{2}$, ce qui est inférieur aux montants investis lors des inventaires antérieurs $\left(7 \$ / \mathrm{km}^{2}\right)$. La diminution des coûts est attribuable à deux facteurs principaux : (1) l'utilisation d'avions à grand rayon d'action (5-7 heures d'autonomie) pour minimiser les déplacements en phase un; (2) l'emploi d'hélicoptères exclusivement pour le dénombrement et le sexage des caribous.

Mots clés : Caribou des bois, Rangifer tarandus caribou, biais, coût, densité, écotype forestier, inventaire aérien, précision, taux de visibilité, simulation, Québec.

The forest-dwelling ecotype of Woodland Caribou (Rangifer tarandus caribou) is found at very low densities and is distributed in small herds dispersed over large areas (Courtois et al. 2001). According to systematic surveys carried out during the 1960s and 1970s, the southern limit of distribution is about the $49^{\text {th }}$ parallel in eastern, and the $50^{\text {th }}$ parallel in western Quebec (Bras- sard $1972 *$ ). These surveys revealed the presence of six large forest-dwelling herds, each comprising from a few hundred to several thousand animals. Outside these herds, a number of scattered smaller groups were also found, composed of 75 or fewer Caribou. Farther south, Woodland Caribou were limited to two small, isolated herds totalling less than 300 individuals. 
Survey techniques for the forest-dwelling ecotype of Caribou have varied considerably over the years depending on the groups being targeted. Large herds were inventoried on traditional wintering areas by means of equidistant transects (Le Hénaff 1976a*,b*; Folinsbee 1979), whereas, the smaller herds in southern Quebec were usually surveyed using total coverage after delimiting the area utilized by means of telemetry (Cantin 1991*; Paré and Brassard 1994*; Desrosiers and Faubert 1995*). No recent estimates are available for the entire forest-dwelling Caribou population. A few estimates have been attempted using random designs, but they were imprecise and probably biased (Joly and Brassard 1980*). Sampling is made difficult by very low densities, usually less than 1.5 Caribou per $100 \mathrm{~km}^{2}$ and by the aggregation of individuals in small groups with clumped distribution (Crête 1991*). In addition, Caribou living in forest habitats are difficult to locate and their visibility has never been estimated in eastern Canada. Some attempts have been made in British Columbia (D. Heard, personal communication, September 2001), but the survey conditions (e.g., snow cover, tree height, canopy cover, group size, etc.) likely differ among regions. Given these difficulties, it has been proposed to monitor only population trends (1) in a few control areas by total coverage (Gingras and Malouin 1993*; Bourbonnais et al. $1997^{*}$ ) or (2) in hunting zones, based on observations made during Moose, Alces alces, surveys (Courtois et al. 1996*). The first approach proved to be effective in estimating the density in relatively small control sites, but turned out to be expensive and the results could not be extrapolated to the entire range (Courtois et al. 1996*). The second approach was inexpensive, but did not allow delimitation of the exact location of each herd, thereby limiting its usefulness for forest management purposes.

Given the lack of an accurate, unbiased and inexpensive survey technique, the present-day locations, abundance and dynamics of forest-dwelling populations are not known (Crête et al. 1990*). This lack of knowledge is of concern, given the precarious situation of forest-dwelling Caribou throughout their range in North America (Mallory and Hillis 1998). Furthermore, for about the last 20 years, there has been a significant northern expansion of forestry operations. As a result, adequate management of forest-dwelling Caribou and their habitat requires a better knowledge of the locations of herds and the population trends. By using the data from two previous surveys, we simulated various sampling scenarios in order to identify a technique that could be applied to large areas. This technique was subsequently tested in a $42539 \mathrm{~km}^{2}$ study site to verify its applicability and to evaluate costs. The feasibility of surveying Woodland Caribou populations over their entire distribution range in Québec is discussed.

\section{Methods}

Thirty survey reports prepared between 1953 and 1997 were used to determine the most suitable periods for surveying forest-dwelling Caribou, as well as the composition of survey teams, types of aircraft and the flying altitude and speed. Data used in the simulations came from two aerial surveys carried out in 1991 and 1993 in two $12000 \mathrm{~km}^{2}$ blocks $\left(\approx 69.0^{\circ} \mathrm{W}, 50.0^{\circ} \mathrm{N}\right.$ and $\approx 63.0^{\circ} \mathrm{W}, 50.5^{\circ} \mathrm{N}$; Gingras and Malouin 1993*; Bourbonnais et al. 1997*). These sites were first totally flown over by airplane in 1991, using north-south transects, and by helicopter in 1992, using transects spaced $10 \mathrm{~km}$ and $3 \mathrm{~km}$, respectively. The sites had been previously divided into plots of $200 \mathrm{~km}^{2}$ (1991) or $100 \mathrm{~km}^{2}$ (1993), and flights allowed the study sites to be classified into two strata according to the presence or absence of Caribou tracks. A sub-sample of plots was then flown over by helicopter using equidistant north-south transects spaced $1 \mathrm{~km}$ apart. The track networks were then flown over at low altitude $(100 \mathrm{~m})$ in order to locate, count and sex individual Caribou. Five plots in each stratum were randomly chosen and surveyed at the beginning of the survey to calculate the Neyman optimal allocation (Snedecor and Cochran 1971), which was thereafter recalculated daily to allocate other plots until a confidence interval (CI) of $25 \%(\alpha=0.10)$ or a sampling rate of $50 \%$ was obtained.

Assuming that these surveys constituted representative pre-tests, we simulated various sampling scenarios in a large, fictitious study site $\left(36000 \mathrm{~km}^{2}\right)$ constructed by randomly selecting sample plots from those flown over in 1991 and 1993. The simulations were set up to completely cover the high-density stratum, since the optimal allocation had suggested surveying all the plots in this stratum during the pre-tests. For the low-density stratum, 50 sampling scenarios were simulated by selecting between two and 100 sample plots. In each case, 100 simulations were carried out. Plots of 100 and $200 \mathrm{~km}^{2}$ were tested, but the results were similar. Thus, only those results obtained with the $100 \mathrm{~km}^{2}$ plots were reported.

Between 20 February and 28 March 1999, we surveyed Caribou in a $42539 \mathrm{~km}^{2}$ study site $\left(\approx 66-71^{\circ} \mathrm{W}\right.$ and $\left.49-51^{\circ} \mathrm{N}\right)$, which included the area covered in 1991. We used a two-phase survey plan. In phase one, two airplanes (Navajo 350), each with a four-member team (pilot, navigator-observer, two observers), flew over the study site using equidistant transects spaced $2.1 \mathrm{~km}$ apart (1.75 minutes of longitude) at a speed of $200 \mathrm{~km} / \mathrm{h}$ and an average altitude of $200 \mathrm{~m}$. The study site had been divided into $40 \mathrm{~km}$ blocks along a northsouth axis in order to limit the length of the transects and to reduce the fatigue of the observers. The territory to be covered was allocated randomly each day between the two teams. Observations (tracks of Caribou, Moose and unidentified cervids) were noted on 1:50 000 topographic maps and their central point was 
positioned using GPS units that were used for navigation. As required, information (e.g., maps, positions of track networks) was exchanged between teams by means of fax and electronic mail.

In phase two, the track networks of Caribou and unidentified cervids were surveyed by helicopters (Bell 206B or Astar 350A) with a three-member team (pilot, navigator-observer, observer) in order to count and classify Caribou (males and females, adults and calves) along the track networks, based on the presence of a vulval patch, and antler and body size. Phase two was usually carried out the day after the phase one survey. During the helicopter counts, the team also noted the presence of radio-collared animals. These Caribou, which numbered 20 in total, were independently radio-located at the middle and at the end of the survey, in order to identify animals that were missed by the observers and to estimate the visibility rate of the Caribou in accordance with the method of Crête et al. (1986: 759). These Caribou had been collared the previous year to ensure their dispersal over the study site. The survey teams were not aware of the locations of marked Caribou at the time of the survey.

\section{Results}

The 30 consulted publications covered 83 aerial surveys of Caribou. Techniques used since the 1950s have varied considerably (Table 1). The most frequently used sampling plan was an inventory of continuous strips spaced systematically within the study areas (11 publications; 25 surveys). Surveys by sample plot (eight publications; 16 surveys) or flying over sites very likely to contain Caribou (seven publications; 38 surveys) were also frequent, the latter technique being used for smaller study areas or when high-density sites had been identified by means of telemetry. Complete coverage or mixed sampling plans were reported in four publications (four surveys). A helicopter (10 publications; 35 surveys) or an airplane (10 publications; 26 surveys) was used more often than an airplane and a helicopter simultaneously (five publications; 11 surveys), while the type of aircraft was not specified in four publications s (11 surveys). The use of airplanes alone was especially frequent in the oldest surveys. Spacing between the flight lines varied between two and $40 \mathrm{~km}$, the widest spacing being used to stratify the study area before counting Caribou. Flight altitude usually varied between 150 and $250 \mathrm{~m}$ and speed was around 150 to $200 \mathrm{~km} / \mathrm{h}$. In open habitats, surveys were usually conducted in fall (mid-September to mid-October) or in late winter (mid-February to late March), whereas only the latter period was used in forested areas.

Surveys carried out in 1991 and 1993 produced results with apparent satisfactory precision, the reported CIs being $20.1 \%$ and $15.6 \%(\alpha=0.10)$, respectively (Table 2). However, the visibility rate had not been estimated, with the result that the population estimates and their variance were likely underestimated since a part of the variation among the sample unit counts was due to visibility bias rather than actual differences in the number of animals present. The low-density stratum contained 18 and $21 \%$ of the Caribou. In 1991, the majority (25 out of 29 ) of groups located during the survey of the plots by helicopter, using transects spaced $1 \mathrm{~km}$ apart, had been detected by airplane during the stratification flight at every $10 \mathrm{~km}$. The area of Caribou track networks averaged $3.1 \mathrm{~km}^{2} \pm 2.8$ (12) (mean \pm standard error $[n]$ ) in 1991 and $0.78 \mathrm{~km}^{2} \pm 0.3$ (12) in 1993.

Variance among plots in the high-density stratum was very high (273.4 and 114.5 in 1991 and 1993, respectively; coefficient of variation [CV]: $129 \%$ and $128 \%$ ), with the result that the Neyman optimal allocation had suggested a complete census of this stratum in both surveys. Most of the variability among plots was due to the heterogeneous distribution of Caribou within the study site, as well as highly variable group sizes (0-49 Caribou per plot in each year). The variance in the low-density stratum was also high given the low numbers of Caribou in these plots $\left(\mathrm{S}^{2}=5.4\right.$ and $0.9 ; \mathrm{CV}=383 \%$ and $427 \%$ ). Most of them were empty, but some contained up to 10 Caribou because some track networks had been overlooked during stratification. This meant the sampling of a large number of plots without Caribou was needed to reduce the variance in this stratum.

For a study site of $36000 \mathrm{~km}^{2}$, the simulations showed that an average CI of $20 \%(\alpha=0.10)$ could be obtained by a complete survey of the high-density stratum, the equivalent of 33 of the $100 \mathrm{~km}^{2}$ plots and 48 of the 327 plots in the low-density stratum (Figure 1a). However with this sampling effort, nearly $60 \%$ of the simulations had a CI higher than the desired threshold of 20\% (Figure 1b). The mean of 100 simulations produced estimates close to the exact value. The mean difference varied between -2.2 to $6.0 \%$ depending on the simulation. In absolute value, the mean error of the estimate diminished with the number of plots surveyed in the low density stratum (Figure 1c). However, it would have been necessary to survey about 80 plots in that stratum to obtain a CI lower than $20 \%$ in about $90 \%$ of the surveys and with a sampling error $<10 \%$ (Figure 1d). Consequently, it appeared to be cheaper to fly at a sufficient intensity in phase 1 to find most of the track networks and then to count all of the Caribou there. In such a survey, the only source of variance would be that of the visibility rate, which could be estimated by means of radio-collared animals.

A preliminary cost estimate was carried out for three sampling designs: (1) stratified random sampling technique (SR) using the airplane and the helicopter (scenario used in 1991); (2) SR using the helicopter only (scenario in 1993); and (3) total coverage of the site by airplane with transects spaced $2.1 \mathrm{~km}$, followed by a helicopter count in the track networks detected by 


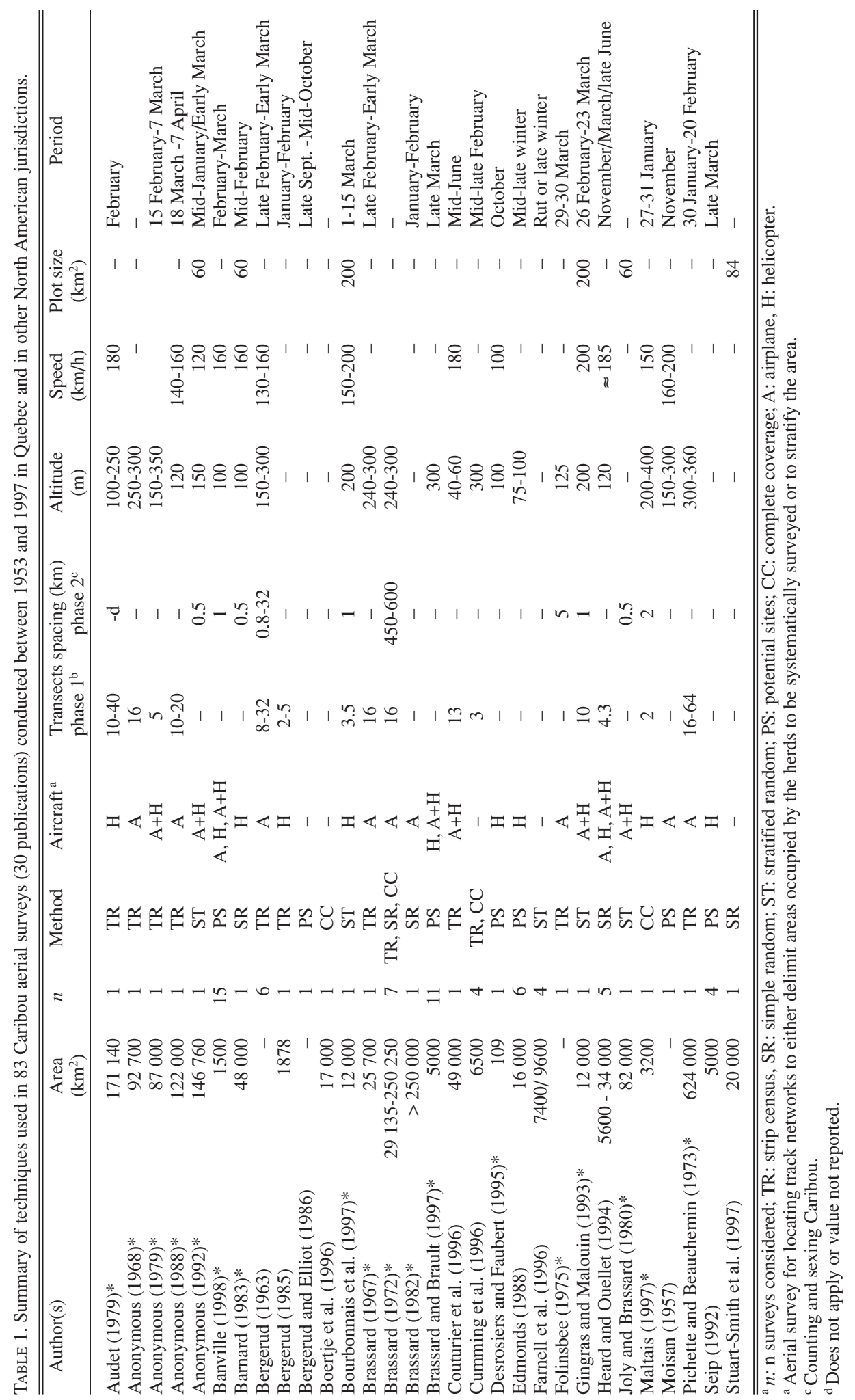


TABLE 2. Results of two aerial surveys of Caribou conducted in 1991 and 1993 in two $12000 \mathrm{~km}^{2}$ study blocks on the North Shore of the St. Lawrence River, Quebec.

\begin{tabular}{|c|c|c|c|c|c|}
\hline Stratum & $\begin{array}{c}\text { Caribou seen } \\
/ 100 \mathrm{~km}^{2}\end{array}$ & $\begin{array}{c}\text { Population } \\
\text { estimate }\end{array}$ & Standard Error & $\mathrm{CI}(\%)^{\mathrm{a}}$ & $\mathrm{f}^{\mathrm{b}}$ \\
\hline \multicolumn{6}{|l|}{1991 SURVEY } \\
\hline High-density & 6.1 & 141 & 0.0 & 0.0 & 1.00 \\
\hline Low-density & 0.3 & 31 & 20.4 & 114.1 & 0.39 \\
\hline Total & 1.4 & 172 & 20.4 & 20.1 & 0.50 \\
\hline \multicolumn{6}{|l|}{1993 SURVEY } \\
\hline High-density & 8.4 & 92 & 0.0 & 0.0 & 1.00 \\
\hline Low-density & 0.2 & 24 & 10.9 & 74.5 & 0.45 \\
\hline Total & 1.0 & 116 & 10.9 & 15.6 & 0.50 \\
\hline
\end{tabular}

a Confidence interval expressed in percentage of the estimated population $(\alpha=0.10)$.

${ }^{\mathrm{b}}$ Sampling rate (number of plots flown / total number of plots).

the plane (Table 3). The third scenario appeared 23$35 \%$ less costly because it did not require a stratification flight and involved less travel between airports and the study site as well as between plots. This scenario also simplified the logistics of the survey and allowed for censuses of Moose and Wolf, Canis lupus, tracks.

In the $42539 \mathrm{~km}^{2}$ study site of 1999, this sampling strategy allowed us to locate 230 Caribou track networks varying in size from 0.06 to $9.52 \mathrm{~km}^{2}(0.53 \pm$ 0.06), and including between 0 and 64 Caribou (2.39 $\pm 0.42)$. The track networks were concentrated in three main sectors (Figure 2). The helicopter crew counted 572 Caribou. Eighteen of the 20 radio-collared Caribou (90\%) were in the track networks identified in the airplane survey (phase one) and of these, 17 (94\%) were observed during phase two using a helicopter. The visibility rate was estimated at 0.90 (SE $=0.067)$ in phase one, and $0.94(0.056)$ in phase two, for an overall rate of $0.85(0.081)$. The total population corrected for the visibility bias was estimated at $673 \pm$ 100 Caribou $(\mathrm{CI}=15 \% ; \alpha=0.10)$. The corrected density was $1.6 \mathrm{Caribou} / 100 \mathrm{~km}^{2} \pm 15 \%$ and there were $60.6 \pm 4.5$ males $/ 100$ females and $16.0 \% \pm 1.4 \%$ calves in the population.

The survey cost of $\$ 160100$ includes the flight time needed to estimate the visibility rate. This figure is about $\$ 17,000$ less than the estimate made during the planning of the survey (Table 3 ). It required $38 \%$ of the budget to fly over the study site, while $13 \%$ was used for airplane travel from and to the airports. The helicopter count represented $13 \%$ of the budget, while $17 \%$ was used for helicopter travel. The rest of the budget (19\%) was used for survey crew lodging and various expenses.

\section{Discussion}

Aerial surveys carried out over the last 50 years illustrate the gregarious behaviour of Caribou, since groups of several dozen to a few thousand individuals have been observed within relatively small areas. Sur- vey techniques have attempted to take advantage of this behaviour. For large northern herds, censuses were generally conducted during calving (Couturier et al. 1996) or post-calving aggregations (Rivest et al. 1994) when animals are concentrated into relatively small open areas making them easier to count.

However, no reliable method exists for Woodland Caribou living in forested habitats. Previous surveys were carried out in winter to take advantage of higher visibility for these animals and to facilitate their detection by means of tracks in the snow. However, the low densities encountered, and the aggregation into groups of variable size led to imprecise estimates. For example, Joly and Brassard (1980*) surveyed Moose and Caribou in $3060-\mathrm{km}^{2}$ sample plots in an $82000 \mathrm{~km}^{2}$ study site south of James Bay $\left(\approx 77.0^{\circ} \mathrm{W}, 50.5^{\circ} \mathrm{N}\right)$. They estimated the Moose population with an acceptable level of precision ( $\mathrm{CI}=25 \%, \alpha=0.10$ ) by utilizing the distribution of track networks that followed a Poisson distribution. However, not enough Caribou track networks were detected to allow the same technique to be applied to this species. In the early $1990 \mathrm{~s}$, $19460-\mathrm{km}^{2}$ plots were surveyed in a $146760 \mathrm{~km}^{2}$ study site located east of James Bay (Anonymous $1992 *)$. Even such a large sampling effort led to a very high CI (14 Caribou/100 km² $\pm 64 \%, \alpha=0.10$ ). During this survey, two high concentration areas were surveyed using transects spaced $10 \mathrm{~km}$ apart. In these smaller areas $\left(\approx 26000 \mathrm{~km}^{2}\right)$, density was estimated at 450 Caribou/ $100 \mathrm{~km}^{2}$ with a $42 \%$ CI.

Previous surveys and our simulations showed that the main Caribou groups must be located and counted in order to reduce the variance in forest-dwelling Caribou surveys. Even in high concentration areas, previous survey techniques usually led to very high variances and significant biases/underestimations due to the gregarious behaviour of forest-dwelling Caribou and because some groups were missed during stratification. According to Bergerud (1963), snow depth may be the main factor influencing the distribution and size of groups, as Caribou become more concentrated in 
Mean confidence interval (\%)

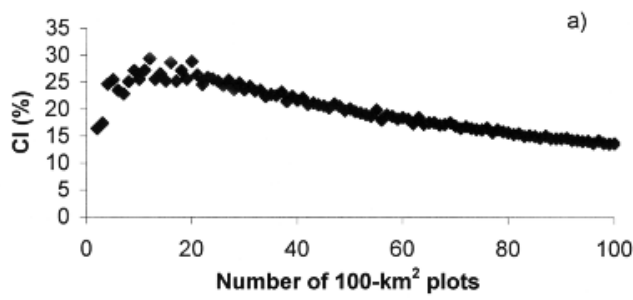

Simulations with confidence interval $>20 \%$

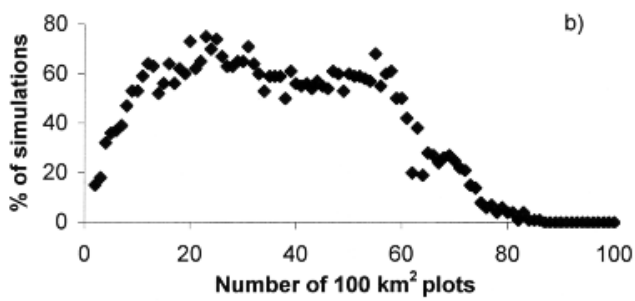

Mean sampling error

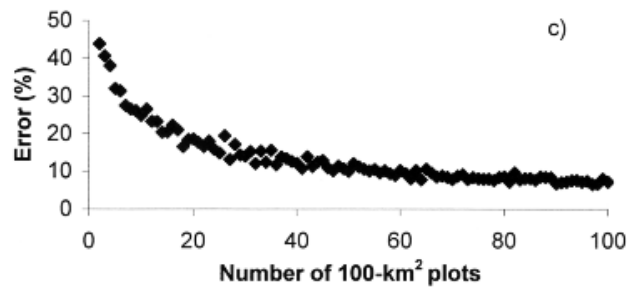

Frequency of sampling error

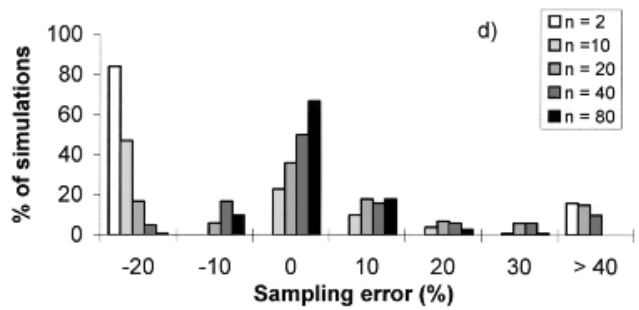

FIGURE 1. Influence of the number of plots surveyed in the low-density stratum (no Caribou track network detected during the stratification flight) on the precision of Caribou aerial surveys in forested habitats. Each point on the curve represents 100 simulations; (a) confidence interval (CI) of the estimated population $(\alpha=0.10)$; (b) $\%$ of simulations producing CIs $>20 \%(\alpha=0.10)$; (c) mean sampling error, in absolute value $(100 *$ [ estimated value - exact value $\mid] /$ exact value), obtained according to the number of plots surveyed; (d) $\%$ of simulations per sampling error class and according to the number of plots surveyed.

deeper snow that limits availability of feeding sites. This author suggested covering the entire study site by plane to locate the main concentration areas $(\geq 232$ Caribou/ $/ 100 \mathrm{~km}^{2}$ ). He then advised surveying these areas in a width-wise direction using strips covering $\geq 33 \%$ of their surface area. In closed habitats, strips should cover about $400 \mathrm{~m}$ on each side of the airplane at $150 \mathrm{~m}$ altitude. Strip width and altitude could be doubled in open habitats. In forested sites, surveys should be carried out when the snow is deepest. The Caribou are thus more concentrated and less inclined to frequent closed habitats in search of arboreal lichens. Bergerud (1963) estimated that this method would underestimate numbers by about $20 \%$ (extremes: 10 $40 \%$ ) in high concentration areas.

We suggest that such a methodology, designed for areas used by large herds of forest-dwelling Caribou, should be applied to the entire study area when densities are very low. In that case, groups of Caribou are small and they occupy relatively small track networks $\left(<3 \mathrm{~km}^{2}\right)$. During the 1991 and 1993 surveys, respectively, 18 and $21 \%$ of the Caribou surveyed were in track networks that were not observed during the stratification flight using transects spaced three to $10 \mathrm{~km}$ apart (Gingras and Malouin 1993*; Bourbonnais et al. $\left.1997^{*}\right)$. In the site surveyed in 1999, the track networks of the three main herds would have probably been detected by a stratification flight made using transects spaced $10 \mathrm{~km}$ apart. However, many isolated track networks would have been missed. These included between 160 and 170 Caribou in total or nearly $30 \%$ of the number surveyed.

With transects spaced $2.1 \mathrm{~km}$ apart, the visibility rate was estimated to be $85 \%$ and a $15 \% \mathrm{CI}(\alpha=0.10)$ was obtained, a precision higher than the acceptable threshold $(20 \%, \alpha=0.10)$ suggested for cervid inventories in North America (Gasaway and Dubois 1987). However, the visibility rate must be considered a first approximation because it was established using a relatively limited number of Caribou and because males were under-represented ( 3 individuals in 20). Surveys should be conducted between mid-February and midMarch, because the Caribou seem more inclined to frequent open habitats during that period. In addition, the observation conditions are better (e.g., sunny, longer and warmer days) than in January.

Based on the 1999 inventory, such a survey cost $\$ 4 / \mathrm{km}^{2}$, which was less than the amount invested for stratified random sampling in areas one third the size of our study site ( $\$ 7 / \mathrm{km}^{2}$; Gingras and Malouin 1993*; Bourbonnais et al. 1997*). Reduction in cost during the 1999 survey was attributed to two main factors: (1) the 
TABLE 3. Estimated cost for the aerial survey of Caribou in a $42539 \mathrm{~km}^{2}$ block according to three sampling scenarios.

\begin{tabular}{|c|c|c|c|}
\hline & Flight time (h) & Aircraft & Cost $(\times \$ 1000)$ \\
\hline \multicolumn{4}{|c|}{$\begin{array}{l}\text { Stratified random sampling (airplane and } \\
\text { helicopter: } 1991 \text { scenario) }\end{array}$} \\
\hline Stratification (10 km interval) & 24.8 & Airplane $^{\mathrm{a}}$ & 9.9 \\
\hline Stratification - travel & 28.3 & Airplane & 11.3 \\
\hline Survey of plots (1 km interval) & 131.0 & Airplane & 52.4 \\
\hline Travel for survey flights & 156.9 & Airplane & 62.8 \\
\hline Counting and sexing & 53.1 & Helicopter ${ }^{b}$ & 37.2 \\
\hline Travel for sexing & 28.3 & Helicopter & 19.8 \\
\hline Lodging & - & - & 40.6 \\
\hline Other & - & - & 3.9 \\
\hline Total & & & 237.9 \\
\hline \multicolumn{4}{|l|}{$\begin{array}{l}\text { Stratified random sampling (helicopter } \\
\text { only: } 1993 \text { scenario) }\end{array}$} \\
\hline Stratification (3.5 km interval) & 75.8 & Helicopter & 53.1 \\
\hline Survey of plots at $1 \mathrm{~km}$ intervals & 129.3 & Helicopter & 90.5 \\
\hline Counting and sexing & 40.7 & Helicopter & 28.5 \\
\hline Travel & 83.6 & Helicopter & 58.5 \\
\hline Sling of fuel & 12.4 & Helicopter & 8.7 \\
\hline Lodging & - & - & 40.6 \\
\hline Other & - & - & 3.9 \\
\hline Total & & & 283.7 \\
\hline \multirow{2}{*}{\multicolumn{4}{|c|}{$\begin{array}{l}\text { Total coverage (airplane and helicopter: } \\
1999 \text { scenario) }\end{array}$}} \\
\hline & & & \\
\hline Survey (2.1 km intervals) & 100.0 & Airplane & 40.0 \\
\hline Airplane travel & 30.0 & Airplane & 12.0 \\
\hline Counting and sexing & 40.7 & Helicopter & 28.5 \\
\hline Helicopter travel & 83.6 & Helicopter & 58.5 \\
\hline Lodging & - & - & 40.6 \\
\hline Other & - & - & 3.9 \\
\hline Total & & & 183.5 \\
\hline
\end{tabular}

a Cost estimated at $\$ 400 / \mathrm{h}$

${ }^{\mathrm{b}}$ Cost estimated at $\$ 700 / \mathrm{h}$

use of long-range airplanes (5-7 hour flight range) to minimize the travel during phase one, and (2) restricted use of helicopters, which are more costly, only for counting and sexing Caribou.

\section{Relevance and Costs of a Forest-Dwelling Caribou Aerial Survey Program}

There are different alternatives to monitor trends of forest-dwelling Caribou populations. For example, changes in distribution (Cumming and Beange 1993), rates of recruitment (Bergerud and Elliot 1986), or survival (Rettie and Messier 1998) had previously been used. However, each method has its own limitations and it would be difficult and costly to use these alternative methods because forest-dwelling Caribou live in low density spread over large areas. Aerial surveys are probably the best source of information to provide distribution, abundance and recruitment estimates simultaneously. This alternative also allows delimiting the area occupied by each herd, which is essential for habitat management purposes.

Information collected over the last 40 years in Quebec shows that the distribution of forest-dwelling
Caribou is limited to the boreal forest (Courtois et al. 2003). More specifically, they are principally found in the eastern part of the bioclimatic zone of spruce/moss forest, where the fire cycle is very long. About $90 \%$ of observations were reported within $\approx 234500 \mathrm{~km}^{2}$, which could be considered as the actual zone of continuous distribution of forest-dwelling Caribou in the province. Using the 1999 survey method, a survey of this area would cost nearly one million dollars. However, about $\$ 257700$ would be sufficient to survey the zones of intensive use $\left(\approx 64400 \mathrm{~km}^{2}\right)$, where about $70 \%$ of Caribou observations have been made (Courtois et al. 2003). The rest of the area frequented by Caribou could be surveyed in an ad hoc fashion, for example, during the planning phase of forest operations. The surveys could be carried out as part of a five-year program in which Moose and Wolf tracks would also be located and the habitats used by Caribou and these two species would be studied.

Isolated herds south of the $49^{\text {th }}$ parallel are already the focus of an aerial survey program. With regards to the forest-dwelling herds in northern Quebec it does 


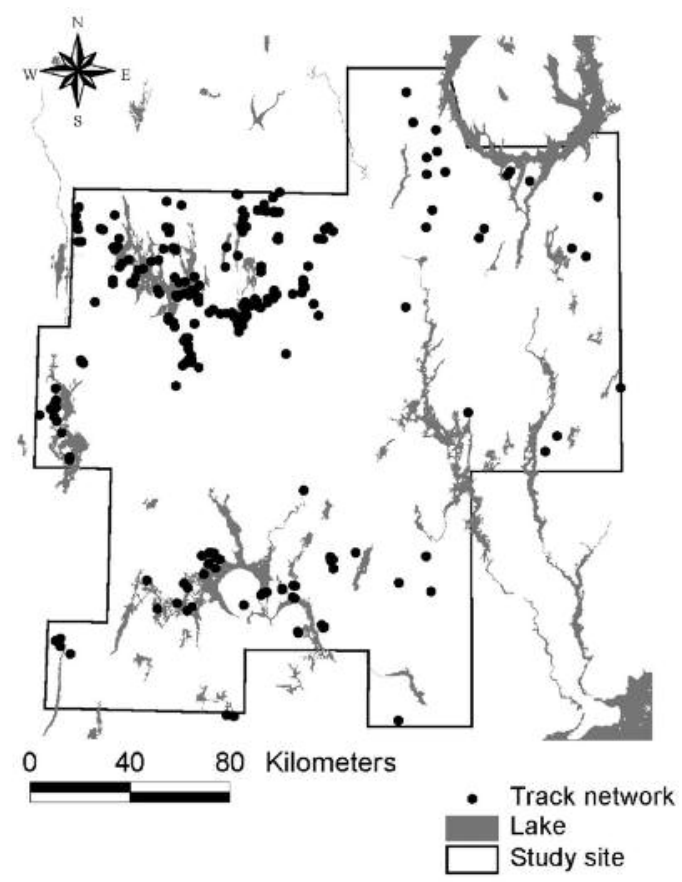

FIGURE 2. Locations of Caribou track networks during the survey of a $42539 \mathrm{~km}^{2}$ study block on the Quebec North Shore, Canada, February and March 1999.

not seem appropriate to survey them because they cooccur with migratory barren-ground Caribou in winter (Paré 1987; Brown et al. 1986; Anonymous 1992*), which prevents unbiased estimates from being obtained.

\section{Acknowledgments}

The authors acknowledge the contribution of the personnel of the Service de l'aménagement et de l'exploitation de la faune at Sept-Îles and Jonquière who provided the aerial surveys. We are particularly indebted to Pierre Drapeau, Christian Dussault, Douglas Heard, François Potvin, James Schaefer and two anonymous referees who reviewed draft versions of this paper and suggested many improvements. This project was financed by the Société de la faune et des parcs du Québec, the Ministère des Ressources naturelles du Québec, the Association des manufacturiers de bois de sciage du Québec, the Fondation de la faune du Québec, Abitibi-Consolidated Inc. and Kruger (Scierie-Manic).

\section{Documents Cited (marked * in text)}

Anonymous. 1968. Inventaire aérien des ongulés sauvages, section située dans le nord de l'Abitibi (janvier 1968). Service de la Faune. Québec, Québec. 7 pages.

Anonymous. 1979. Inventaire aérien des ongulés de la CôteNord, 1979. Hydro-Québec, Direction de l'Environnement. Montréal, Québec. 5 pages + appendix.
Anonymous. 1988. Late winter distribution of caribou and moose in southern Labrador and the Québec North Shore. Renewable Resources Consulting Services Ltd., Sidney, B.C. and S. Fudge and Associates Limited, St. John's, Newfoundland. 27 pages.

Anonymous. 1992. Complexe Nottaway-Broadback-Rupert: Les mammifères - volume 3 - Abondance et habitat du caribou (Rangifer tarandus). Hydro-Québec, Vice-présidence Environnement, Montréal, Québec. 55 pages + appendix.

Audet, R. 1979. Inventaire aérien de l'ensemble du bassin versant de la moyenne et de la basse Côte-Nord. HydroQuébec, Direction de 1'Environnement. Montréal, Québec. 42 pages.

Banville, D. 1998. Plan de gestion du caribou de Charlevoix. Ministère de l'Environnement et de la Faune. Charlesbourg, Québec. 26 pages.

Barnard, F. 1983. Rapport de l'inventaire aérien des ongulés de la basse Côte-Nord en février 1983. Ministère du Loisir, de la Chasse et de la Pêche. Sept-Îles, Québec. 11 pages.

Bourbonnais, N., A. Gingras, and B. Rochette. 1997. Inventaire aérien du caribou dans une portion de la zone de chasse 19 sud (partie est) en mars 1993. Ministère de l'Environnement et de la Faune. Sept-Îles, Québec. 11 pages.

Brassard, J.-M. 1967. Inventaire aérien des ongulés sauvages de la Côte-Nord et identification des aires d'hivernement en fonction des formes du relief et de la végétation. Service de la Faune. Québec, Québec. 15 pages.

Brassard, J.-M. 1972. Inventaire aérien du gros gibier. Ministère du Tourisme, de la Chasse et de la Pêche. Québec, Québec. 39 pages.

Brassard, J.-M. 1982. Inventaire aérien du caribou des territoires situés sur les versants de la Côte-Nord du SaintLaurent. Ministère du Loisir, de la Chasse et de la Pêche. Québec, Québec. 13 pages.

Brassard, C., and M. Brault. 1997. État de la situation du caribou des bois (Rangifer tarandus caribou) de la CôteNord du Saint Laurent. Ministère de l'Environnement et de la Faune, Baie-Comeau, Québec. 62 pages.

Cantin, M. 1991. Tendances démographiques de la population de caribous (Rangifer tarandus) des Grands-Jardins. Ministère du Loisir, de la Chasse et de la Pêche. Charlesbourg, Québec. 26 pages.

Courtois, R., F. Potvin, S. Couturier, and A. Gingras. 1996. Révision des programmes d'inventaires aériens des grands cervidés. Ministère de l'Environnement et de la Faune. Québec, Québec. 49 pages.

Crête, M. 1991. Mise au point de la technique d'inventaire du caribou dans la taïga. Ministère du Loisir, de la Chasse et de la Pêche. Québec, Québec. 20 pages.

Crête, M., R. Nault, and H. Laflamme. 1990. Caribou. Ministère du Loisir, de la Chasse et de la Pêche. Québec, Québec. 73 pages.

Desrosiers, A., and R. Faubert. 1995. Méthode d'inventaire aérien pour déterminer la composition automnale de la population de caribous du parc de la Gaspésie et synthèse des résultats obtenus entre 1953 et 1994 . Ministère du Loisir, de la Chasse et de la Pêche. Québec, Québec. 22 pages.

Folinsbee, J. D. 1975. An aerial survey of the Lac Joseph Caribou Herd, March 1975. Newfoundland Wildlife Service, St. John's, Newfoundland. 14 pages. 
Gingras, A., and B. Malouin. 1993. Inventaire aérien du caribou dans la zone de chasse 19 sud (partie ouest) en mars 1991. Ministère du Loisir, de la Chasse et de la Pêche. Sept-Îles, Québec. 26 pages.

Joly, R., and J.-M. Brassard. 1980. Inventaire aérien des ongulés d'une portion sud du territoire de la municipalité de la Baie James. Ministère du Loisir, de la Chasse et de la Pêche. Québec, Québec. Report DGF 16: 116-136.

Le Hénaff, D. 1976a. Vérification des principales aires du caribou (Rangifer tarandus) dans le secteur de Waco (basse Côte-Nord) et au Nouveau Québec, avril 1976. Ministère du Tourisme, de la Chasse et de la Pêche. Québec, Québec. 31 pages.

Le Hénaff, D. 1976b. Inventaire aérien du secteur Natashquan à Blanc-Sablon. Ministère du Tourisme, de la Chasse et de la Pêche. Québec, Québec. 7 pages.

Maltais, J. 1997. Inventaire de reconnaissance (aire commune 24-1): caribous des bois (Rangifer tarandus) de la région des lacs Péribonca et Manouane. Abondance et besoins de l'espèce par rapport à l'exploitation forestière. Stone-Consolidated Inc., Division Saguenay. Chicoutimi, Québec. 39 pages + appendix.

Paré, M., and C. Brassard. 1994. Écologie et plan de protection de la population de caribous de Val-d'Or. Ministère de l'Environnement et de la Faune. Rouyn-Noranda, Québec. 56 pages.

Pichette, C., and P. Beauchemin. 1973. Inventaire aérien du caribou. Ministère du Tourisme, de la Chasse et de la Pêche. Québec, Québec. 11 pages.

\section{Literature Cited}

Bergerud, A. T. 1963. Aerial census of caribou. Journal of Wildlife Management 27: 438-449.

Bergerud, A. T. 1985. Antipredator strategies of caribou: dispersion along shorelines. Canadian Journal of Zoology 63: 1324-1329.

Bergerud, A. T., and J. P Elliot. 1986. Dynamics of caribou and wolves in Northern British Columbia. Canadian Journal of Zoology 64: 1515-1529.

Boertje, R. D., P. Valkenburg, and M. E. McNay. 1996. Increases in moose, caribou, and wolves following wolf control in Alaska. Journal of Wildlife Management 60: 474-489.

Brown, W., J. Huot, P. Lamothe, M. Paré, G. St-Martin, and J. B. Theberge. 1986. The distribution and movement patterns of four woodland caribou herds in Quebec and Labrador. Rangifer, Special Issue 1: 43-49.

Courtois, R., J.-P. Ouellet, A. Gingras, C. Dussault, and D. Banville. 2001. La situation du caribou forestier au Québec. Naturaliste Canadien 128: 53-63.

Courtois, R., J.-P. Ouellet, A. Gingras, C. Dussault, L. Breton, and J. Maltais. 2003. Historical changes and current distribution of Caribou, Rangifer tarandus, in Quebec. Canadian Field-Naturalist 117: 399-414.

Couturier, S., R. Courtois, H. Crépeau, L.-P. Rivest, and S. Luttich. 1996. The June 1993 photocensus of the Rivière George caribou herd and comparison with an independent census. Rangifer, Special Issue 9: 283-296.
Crête, M., L.-P. Rivest, H. Jolicoeur, J.-M. Brassard, and F. Messier. 1986. Predicting and correcting helicopter counts of moose with observations made from fixed-wing aircraft in southern Québec. Journal of Applied Ecology 23: 751-761.

Cumming, H. G., and D. B. Beange. 1993. Survival of woodland caribou in commercial forests of northern Ontario. Forestry Chronicle 69: 579-588.

Cumming, H. G., D. B. Beange, and G. Lavoie. 1996. Habitat partitioning between woodland caribou and moose in Ontario: the potential role of shared predation risk. Rangifer, Special Issue 9: 81-94.

Edmonds, E. J. 1988. Population status, distribution and movements of woodland caribou in west central Alberta. Canadian Journal of Zoology 66: 817-826.

Farnell, R., N. Barichello, K. Egli, and G. Kuzyk. 1996. Population ecology of two woodland caribou herds in the southern Yukon. Rangifer, Special Issue 9: 63-72.

Folinsbee, J. D. 1979. Distribution et abondance passées et présentes du caribou (Rangifer tarandus) au Labrador méridional et dans les régions adjacentes du Québec. Recherches Amérindiennes au Québec 9: 37-46.

Gasaway, W. C., and S. D. Dubois. 1987. Estimating moose population parameters. Swedish Wildlife Research, Supplement 1: 603-617.

Heard, D., and J.-P. Ouellet. 1994. Dynamics of an introduced caribou population. Arctic 47: 88-95.

Mallory, F. F., and T. L. Hillis. 1998. Demographic characteristics of circumpolar caribou populations: ecotypes, ecological constraints/releases, and population dynamics. Rangifer, Special Issue 10: 49-60.

Moisan, G. 1957. Le caribou de Gaspé. III: Analyse de la population et plan d'aménagement. Naturaliste Canadien 84: 5-27.

Paré, M. 1987. Effets du remplissage d'un réservoir hydroélectrique sur la population de caribous de Caniapiscau. M.Sc. thesis, Université Laval. Québec, Québec. 141 pages.

Rettie, W. J., and F. Messier. 1998. Dynamics of Woodland caribou populations at the southern limit of their range in Saskatchewan. Canadian Journal of Zoology 76: 251-259.

Rivest, L.-P., S. Couturier, and H. Crépeau. 1994. Statistical methods for estimating caribou abundance using post-calving aggregations detected by radiotelemetry. Biometrics 54: $865-876$

Seip, D. R. 1992. Factors limiting woodland caribou populations and their interrelationships with wolves and moose in southeastern British Columbia. Canadian Journal of Zoology 70: 1494-1503.

Snedecor, G. W., and W. G. Cochran. 1971. Méthodes statistiques, 6 e édition. Association de coordination technique agricole. Paris, France. 649 pages.

Stuart-Smith, A. K., C. J. A. Bradshaw, S. Boutin, D. M. Hebert, and A. B. Rippin. 1997. Woodland caribou relative to landscape pattern in northeastern Alberta. Journal of Wildlife Management 61: 622-633.

Received 30 October 2001

Accepted 12 February 2004 